\title{
ORTODONTINIO GYDYMO ITAKA PAŽEISTIEMS PERIODONTO AUDINIAMS
}

\author{
Jūratė Žekonienė, Laura Linkevičienė, Modesta Ralytė \\ Vilniaus universiteto Medicinos fakulteto Odontologijos institutas
}

Raktažodžiai: periodontologinis-ortodontinis gydymas, pažeisti periodonto audiniai, ortodontinis gydymas ir periodonto patologija.

\section{Santrauka}

Periodonto ligos yra vienos labiausiai paplitusių ligų pasaulyje, o didesnis jų dažnis stebimas suaugusių žmonių populiacijoje. Dèl estetikos, efektyvios kramtymo funkcijos ir geresnès gyvenimo kokybès siekio suaugę žmonès, dažnai jau turintys periodonto patologijos pažeistų audinių, nori pradèti ortodontinį gydymą. Esant stabiliai paciento periodonto audinių būklei, pastarasis gydymas nèra kontraindikuotinas, tačiau prieš praktiškai sprendžiant tokias klinikines situacijas, reikia žinoti, kokią ịtaką ortodontinis gydymas turi pažeistiems periodonto audiniams.

Tyrimo tikslas - atlikti mokslinès literatūros analizę ir pateikti mokslinį pagrindimą šiais ortodontinio gydymo itakos pažeistiems periodonto audiniams aspektais: 1) pažeistų periodonto audinių uždegiminiai ir mikrobiologiniai pokyčiai ortodontinio gydymo metu, 2) ortodontinių judesių įtaka pažeistiems periodonto audiniams, 3) kombinuoto ortodontinio-periodontologinio gydymo perspektyva, 4) neigiama ortodontinio gydymo įtaka pažeistiems periodonto audiniams.

Tyrimo medžiaga ir metodai: moksliniai straipsniai, publikuoti 2000-2021 m. laikotarpiu, ieškoti Medline (per PubMed), Google Scholar ir ScienceDirect mokslinių duomenų bazèse. Literatūros šaltiniai atrinkti remiantis šiais kriterijais: 1) straipsniai, kuriuose aprašomas periodontologinio paciento ortodontinis gydymas, 2) straipsniai, ịrodantys teigiamą (neigiamą) ortodontinio gydymo poveiki periodontologinių defektų at(si)kūrimui, 3) straipsniai, nurodantys aspektus, $i$ kuriuos turi atsižvelgti periodontologinį-ortodontini gydymo planą vykdantys gydytojai.

Išvados. Esant stabiliai periodonto audinių būklei, ortodontinis gydymas nèra kontraindikuotinas ir dažniausiai turi teigiamą efektą pažeistų periodonto audinių atsikūrimui. Uždegiminiai ir mikrobiologiniai pokyčiai pažeistuose periodonto audiniuose pradejjus ortodontinį gydymą stebimi, tačiau neigiama linkme neprogresuoja ir aktyvios periodontologinès ligos nesukelia. Ortodontinių judesių metu alveolinis kaulas daugiau nesirezorbuoja, kai kur vyksta jo apozicija, galimos periodonto patologijos sukeltų kaulinių ir minkštujų audinių defektų korekcijos, užkertamas kelias tolesnei danties palaikomojo aparato destrukcijai. Klinikiniai periodonto sveikatos rodikliai po kombinuoto periodontologinio-ortodontinio gydymo yra geresni, lyginant su pasiektais tik po periodontologinio gydymo. Neigiama ortodontinio gydymo įtaka periodonto audiniams apima pablogèjusị vainiko- šaknies santykị, dantų paslankumą ar netgi jų netekimą.

\section{Ivadas}

Periodontologinio gydymo tikslas yra sustabdyti periodonto audinių destrukciją, atkurti jų sveikatą ir danties palaikomojo aparato integralumą. Ortodontinio gydymo - dantų ir veido estetikos kūrimas kartu su taisyklingo sąkandžio ir normalios kramtymo funkcijos užtikrinimu [1]. Pastarojo gydymo esmè dažnai vadinama ,periodonto fenomenu“, nes išskirtinai priklauso nuo periodonto audinių: jų remodeliacijos galimybiu, alveolinio kaulo topografijos, danties šaknies ilgio ir formos, dantenų anatomijos ir kontūro [1,2]. Dèl glaudaus šių odontologijos sričių santykio kyla klausimas - ị ką gydytojams reikètų atsižvelgti, kai ortodontiškai planuojama gydyti periodonto liga sergantị pacientą.

Periodontitu serga 743 milijonai žmonių visame pasaulyje. Periodonto ligos yra laikomos didžiulę naštą sukeliančiomis ligomis ir aprèpia nuo 20 iki 50 proc. ivvairių šalių gyventojų (aprèptis didèja, didejjant amžiui), o gerejant socioekonominèms sąlygoms ir odontologijos mokslo galimybėms, vis daugiau periodonto patologiją turinčių žmonių pageidauja ortodontinio gydymo [3-5]. J. Hirschfeld ir kolegų (2019) tyrimo duomenimis, beveik 70 proc. periodontitu sergančių suaugusių pacientų (didžioji dalis apklaustųjų buvo 
per 50 metų), nepriklausomai nuo jų lyties, demografinès padèties ir periodontito stadijos, pageidautų ortodontinio gydymo [6]. Tokiu gydymu pasiekiama periodonto audinių homeostazé, o gydytojų periodontologo ir ortodonto bendradarbiavimas ir kompleksinio gydymo planavimas reikalingas esant dantų tarpams, ekstruzijai, migracijai, okliuzinei traumai ir kitiems periodonto patologijos padariniams [7]. Vis dèlto, prieš praktiškai sprendžiant tokius klinikinius atvejus, reikia žinoti, kaip pažeisti periodonto audiniai reaguoja i ortodontinị gydymą.

Tyrimo tikslas - atlikti mokslinès literatūros analizę ir pateikti mokslini pagrindimą šiais ortodontinio gydymo ịtakos pažeistiems periodonto audiniams aspektais: 1) pažeistu periodonto audinių mikrobiologiniai pokyčiai ortodontinio gydymo metu, 2) ortodontinių judesių įtaka pažeistiems periodonto audiniams, 3) kombinuoto ortodontinio - periodontologinio gydymo perspektyva, 4) neigiama ortodontinio gydymo įtaka pažeistiems periodonto audiniams.

\section{Tyrimo medžiaga ir metodai}

Mokslinių straipsnių, publikuotų 2000-2021 m. laikotarpiu, ieškota Medline (per PubMed), Google Scholar ir ScienceDirect mokslinių duomenų bazėse. Paieškoje naudotos raktažodžių kombinacijos: orthodontic and periodontal treatment, orthodontics and periodontics interrelationship or relationship, orthodontic treatment of periodontitis patient, orthodontic treatment of periodontally compromised patient, orthodontics and periodontal disease. Literatūros šaltiniai atrinkti remiantis šiais kriterijais: 1) straipsniai, kuriuose aprašomas periodontologinio paciento ortodontinis gydymas, 2) straipsniai, ịrodantys teigiamą (neigiamą) ortodontinio gydymo poveikị periodontologinių defektų atsistatymui, 3) straipsniai, nurodantys aspektus, i kuriuos turi atsižvelgti periodontologinị-ortodontini gydymo planą vykdantys gydytojai.

\section{Tyrimo rezultatai ir diskusija}

Pažeistų periodonto audinių uždegiminiai ir mikrobiologiniai pokyčiai ortodontinio gydymo metu. Ortodontinio gydymo metu generuojamos mechaninès jejgos skatina interleukinų, prostaglandinų ir kitų uždegiminių veiksnių, aktyviai veikiančių ir periodontito atveju, išsiskyrimą periodonto audiniuose [8]. Ortodontiniai prietaisai yra tinkama vieta bakterinès bioplèvelès formavimuisi ir retencijai, todèl ilgainiui burnos mikrofloros ekosistema kinta ir ima dominuoti gramneigiami anaerobai - pagrindiniai periodonto audinių patogenai [8]. Patogeniškais gali tapti ir virš dantenų buvę, bet dèl ortodontinio gydymo indukuotos dantenų hipertrofijos po dantenomis (pseudokišenèse) atsidūrę ir tinkamai nepašalinami mikroorganizmai. Šie pakitimai stebimi ir periodonto liga nesirgusiems pacientams, todèl teigiama, kad pažeistų audinių atveju norint išvengti tolesnès danties palaikomojo aparato audinių destrukcijos, juos reikia vertinti dar atidžiau [8]. Periodontitu sergančiu suaugusių pacientų periodonto audiniuose per pirmas šešias ortodontinio gydymo savaites pastebimas reikšmingas periodontologines ligas skatinančių patogenų Campylobacter rectus, Veilonella, Peptostreptococcus, Actinomyces viscosus, Bacterionema rothia skaičius, tačiau, esant tinkamai periodonto audinių sveikatos priežiūrai, jis išlieka stabilus ir aktyvios periodonto ligos nesukelia [9]. Kiti in vivo tyrimų autoriai taip pat pastebi, kad atsakingai kontroliuojant periodontitu sergančio paciento periodonto audinių būklę ortodontinio gydymo metu, uždegiminiai ir mikrobiologiniai pokyčiai nedaro neigiamo poveikio periodonto sveikatai: A. actinomycetemcomitans, $P$. gingivalis, $T$. forsythia ir $T$. dentincola bakterijų skaičius per pirmajį ortodontinio gydymo pusmeti ir matrikso metalo proteinazių kiekis dantenų vagelès skystyje 21 dienos laikotarpiu reikšmingai nedidèja, o kraujavimas po zondavimo, ortodontinio gydymo pradžioje galintis siekti 90 proc., po 4-6 ortodontinio gydymo mènesių sumažeja iki 20 procentų [10,11].

Ortodontinių judesių įtaka pažeistiems periodonto audiniams. Ortodontinio gydymo mechanizmas yra paremtas periodonto raiščio ir alveolinio kaulo modifikacijomis: šio gydymo metu sukuriamos spaudimo ir tempimo zonos kraštiniame ir viršūniniame periodonte, atitinkamai lemiančios kaulo rezorbciją ir apoziciją [12]. Periodonto ligos sukeltuc burnos audinių defektų turintiems pacientams (net jei aktyvi ligos fazè jau suvaldyta) toks gydymas galètų būti žalingas, tačiau klinikinių tyrimų rezultatai rodo labai pozityvią ortodontinio gydymo įtaką anksčiau pažeistiems periodonto audiniams. Pirmiausia, ortodontinio gydymo pagalba ištiesinti dantų lankai gerina dantų savaiminị apsivalymą, palengvina asmeninę burnos higieną ir tuo prisideda prie periodonto audinių sveikatos palaikymo [13]. 2019 metais paskelbtame eksperimentiniame tyrime aptariamas vienas aktualiausiu klausimu - tolesnis alveolinio kaulo praradimas, pradejjus periodonto pažeistų audinių ortodontinį gydymą [14]. Šiame tyrime reikšmingų alveolinio kaulo kiekio skirtumų, lyginant prieš ir po ortodontijos gautus kūginio pluošto kompiuterinés tomografijos rezultatus (nesvarbu, ar periodontologinis gydymas atliktas prieš ortodontini gydymą, ar jo metu ir nepriklausomai nuo amžiaus, lyties, sąkandžio bei gydymo trukmès), nebuvo pastebèta. Mezialiniuose ir distaliniuose paviršiuose, priešingai nei skruostiniuose ar liežuviniuose, buvo nustatytas kaulinio audinio atsidejjimas (tai įmanoma dèl ortodontinio tarpų uždarymo), o retruduojant (8,6 laipsniais) ir intruduojant (daugiau nei 1,6 mm) stipriai protruduotus viršutinio žandikaulio kandžius, kaulo regeneracija 
liežuviniame paviršiuje stebèta vidutiniškai net apie $1 \mathrm{~mm}$ [14]. C. Ramachandra ir kolegos ịrode, jog intruziniais ir retrakciniais ortodontiniais judesiais seklus ir horizontalus kaulinis defektas, ne taip gerai reaguojantis ị nukreipiamosios regeneracijos periodontologinị gydymą, gali būti pakeistas i gerą gydymo prognozę po grafting'o žadantị siaurą ir gilų vertikalų defektą [2]. Kiti autoriai teigia, jog ortodontiniu gydymu pakoreguotas sukandimas leidžia tolygiau paskirstyti rezorbuotam alveoliniam kaului tenkančias jëgas ir nespartina horizontalios kaulo rezorbcijos, todèl gereja žmogaus kramtymo funkcija [15]. Dèl periodonto patologijos prasidejjusi okliuzinè trauma sukelia vis didesnę dantų migraciją, o šiai esant dantys dar labiau traumuojami, tačiau taisyklingesnès jų padèties atkūrimas ortodontiškai leidžia to išvengti [13]. Periodonto patologijos sukelta priekinių dantų ekstruzija gali būti sèkmingai koreguojama ortodontine intruzija. E. Zasčiurinskienès ir kolegų sisteminèje apžvalgoje randamas ne vienas tyrimas, rodantis reikšmingą periodonto kišenių gylio, recesijų sumažejjimą ir prisitvirtinimo jungties atsikūrimą intruduojant ekstruduotus kandžius [16]. S. Re ir klinikinio tyrimo bendraautoriai prie tokių pat išvadų pridejo ir faktą, kad periodonto biotipas (storas ar plonas) tokiems rezultatams ịtakos neturi [17]. Minètas ekstruzinis judesys, sukurdamas tempimą periodonto raištyje, skatina kaulo atsidèjimą, todèl jo pagalba gali būti koreguojami 1 ir 2 sienelių kauliniai [18] arba furkaciniai defektai - pirmojo viršutinio žandikaulio kaplio tokio defekto gydymas buvo sèkmingas po regeneracinių periodontologinių procedūrų ir vèliau pritaikytos ortodontinès ekstruzijos [12]. Sèkmingą kaulinių defektų korekciją ịrodo ir eksperimentai su gyvūnais: kampiniai kauliniai defektai, naudojant jų link nukreiptą kūnišką dantų judesị, akivaizdžiai gijo eksperimentuose su beždžionėmis, šunų III klasès furkaciniai defektai visiškai atsistatė arba, panaudojus intruzines jègas, virto i I ar II klasès defektus, mezialinis dantų pavertimas žiurkių žandikauliuose indukavo kaulo atsidejjimą, o šunims dirbtinai sukelto periodontito atveju panaudota ekstruzija sumažino periodonto kišenių gylį, dantenų uždegimą, kraujavimą po zondavimo ir paskatino kaulo apoziciją $[3,12]$. Periodonto liga sirgę pacientai dažnai skundžiasi ,juodaisiais trikampiais“ (tarpdantinès dantenos spenelio pažemèjimu). Šią problemą taip pat galima koreguoti ortodontiškai: artinant dantų šaknis viena kitos link, keičiama alveolinio kaulo keteros morfologija, kontaktinis dantų taškas pasislenka šaknies viršūnès link ir suspaudžiamas dantenų spenelis lengviau užpildo atsiradusị tarpdantinį tarpą $[19,20]$. Dél periodontito praradus dantis, buvusieji su jais kontakte keičia savo padèti (dažniausiai, netekus mezialiau esančio danties, $i$ jo pusę pasvyra krūminiai dantys), o toje vietoje atsiranda periodonto kišenès bei kauliniai defektai. Per 3-6 mènesius trunkantị ortodontini gydymą tokio danties padètis atkuriama ị taisyklingą, kaulinis defektas sumažinamas ir suformuojamas taisyklingesnis dantenų kontūras [19]. Ortodontinių judesių itaka pažeistiems periodonto audiniams yra dažnas eksperimentinių mokslinių tyrimų tikslas, tačiau sisteminè apžvalga ir metaanalizè, jungianti jų rezultatus, buvo publikuota tik šiemet [21]. Pagrindinè jos išvada - tolesnis periodonto jungties netekimas ar periodonto kišenių gylio didèjimas, pradèjus ortodontini gydymą po periodontologinio (esant stabiliai periodonto audinių būklei), nestebimas [21]. I antrajji autorių išsikeltą tikslą - išsiaiškinti laikinų ortodontinès atramos aparatų efektyvumą, naudojant juos periodontologinių pacientų gydymui - sisteminè duomenų analizè atsakyti negalejo dèl mokslinių tyrimų trūkumo. Galima teigti, kad ortodontinių judesių ir pažeistų periodonto audinių sąsaja išlieka aktualus ateities mokslinių tyrimų tikslas [21].

Kombinuoto periodontologinio - ortodotinio gydymo perspektyvos. Periodonto audinių defektus galima gydyti vien tik periodontologiniais metodais, tačiau moksliniai tyrimai rodo, kad toki gydymą savo efektyvumu kai kuriais atvejais pranoksta kombinuotas periodontologinis-ortodontinis gydymas [22]. J. Zhang ir kolegos (2017) atliko tyrimą, kurio metu vertino dèl periodontito patologinę dantų migraciją turinčių pacientų periodonto audinių sveikatos rodiklių: zondavimo gylio, dantų paslankumo, apnašų indekso, kraujavimo po zondavimo, jungties prisitvirtinimo lygio pokyčius, pacientus gydant tik gydytojui periodontologui ir komandoje - gydytojams periodontologui ir ortodontui kartu. Eksperimento rezultatai parodè, kad abu gydymo planai minètus rodiklius pagerino, tačiau kombinuota technika pasiekti rezultatai po 18 ménesių gydymo buvo reikšmingai geresni, lyginant su tik periodontologiškai gydytujų grupe ir beveik nesiskyré nuo sveikų (periodontitu nesirgusių) pacientų rodiklių. Tarpdisciplininio gydymo tiriamuju grupejje nustatyti mažesni kraujavimo po zondavimo ir apnašų indeksai bei greitesnis uždegiminių mediatorių dantenų vagelès skystyje sumažejjimas pradejjus gydymą (lyginant tik su periodontologiškai gydytujų grupe), yra akivaizdūs įrodymai, kad pacientų motyvacija, edukacija ir stebejjimas leidžia sèkmingai kontroliuoti pažeistų periodonto audinių sveikatą ortodontinio gydymo metu [22]. C. Martin ir kolegų publikuotoje sistemineje apžvalgoje taip pat daroma išvada, jog radiologinis kaulo atsikūrimas yra didesnis tiems pacientams, kurie prieš ortodontini gydymą buvo gydomi regeneracinès periodontologijos metodais [21].

Neigiama ortodontinio gydymo įtaka pažeistiems periodonto audiniams. Periodontologinio paciento ortodontinis gydymas nèra kasdienis atvejis, todèl be teigiamų gydymo efektų laukimo gydytojai ortodontai ir periodontologai turetų gerai išmanyti bei iš anksto numatyti ir neigiamus. Pavyz- 
džiui, nors vertikalūs kauliniai defektai nėra kontraindikacija ortodontiniam gydymui [23], keletas autorių įspejja apie galimas komplikacijas: dantu judesys kampinio defekto link arba tokių dantų intruzija gali paskatinti alveolinio kaulo rezorbciją, o net ir suvaldžius bakterinę infekciją, periodonto jungties atsikūrimas tokių defektų srityse stebimas ne visada [15]. Jei skruostinis - liežuvinis alveolinio kaulo matmuo yra sumažejęs ir dantis juda per kortikalinį kaulą, gali atsirasti dehiscencijų [24]. Periodontologinio paciento ortodontinio gydymo rizika apibrěžiama galimu minkštujų audinių praradimu, alveolinio kaulo destrukcija arba išorine šaknies rezorbcija, o šių procesų pasekmès stebimos kaip pablogèjęs vainiko - šaknies santykis, dantų paslankumas ar netgi jų netekimas [3].

\section{Išvados}

1. Esant stabiliai periodonto audinių būklei, ortodontinis gydymas nėra kontraindikuotinas ir dažniausiai turi teigiamą efektą pažeistų periodonto audinių atsikūrimui.

2. Uždegiminiai ir mikrobiologiniai pokyčiai pažeistuose periodonto audiniuose pradejus ortodontini gydymą stebimi, tačiau neprogresuoja neigiama linkme ir aktyvios periodontologinès ligos nesukelia.

3. Ortodontiniu judesių metu alveolinis kaulas daugiau nesirezorbuoja, kai kur vyksta jo apozicija, galimos periodonto patologijos sukeltų kaulinių ir minkštụjų audinių defektų korekcijos, užkertamas kelias tolesnei danties palaikomojo aparato destrukcijai.

4. Klinikiniai periodonto sveikatos rodikliai po kombinuoto periodontologinio-ortodontinio gydymo yra geresni, lyginant su pasiektais tik po periodontologinio gydymo.

5. Neigiama ortodontinio gydymo įtaka periodonto audiniams apima pablogèjusị vainiko-šaknies santykị, dantų paslankumą ar jų netekimą.

\section{Literatūra}

1. Humgain M, Kafle D. Current Updates on the Orthodontic-Periodontic Interralationship. In: Mark Bartol P, Kemal Y, editors. Current issues in periodontics. Adelaide, Australia: Asian Pacific Society of Periodontology 2015:101-109.

2. Ramachandra CS, Shetty PC, Rege S, Shah C. Ortho-perio integrated approach in periodontally compromised patients. J Indian Soc Periodontol 2011;15(4):414-7.

https://doi.org/10.4103/0972-124X.92583

3. Zasčiurinskienė E. Studies on orthodontic treatment in subjects with periodontal disease. 2018.

4. Nazir M, Al-Ansari A, Al-Khalifa K, Alhareky M, Gaffar B, Almas K. Global Prevalence of Periodontal Disease and Lack of Its Surveillance. Sci World J 2020;2020.

https://doi.org/10.1155/2020/2146160
5. Papapanou PN, Susin C. Periodontitis epidemiology: is periodontitis under-recognized, over-diagnosed, or both? Periodontol 2000 2017;75(1):45-51.

https://doi.org/10.1111/prd.12200

6. Hirschfeld J, Reichardt E, Sharma P, Hilber A, Meyer-Marcotty P, Stellzig-Eisenhauer A, et al. Interest in orthodontic tooth alignment in adult patients affected by periodontitis: A questionnaire-based cross-sectional pilot study. J Periodontol 2019;90(9):957-65.

https://doi.org/10.1002/JPER.18-0578

7. Rodríguez-Pulido JI, Villarreal-Guerra MO, Martínez-Sandoval G, Garza-Enríquez M, Akemi Nakagoshi-Cepeda MA. Orthodontic treatment in the periodontally compromised patient: A case report. Int J Appl Dent Sci 2018;4(3):14-7.

8. Reichert C, Hagner M, Jepsen S, Jäger A. Schnittstellen zwischen kieferorthopädischer und parodontaler Therapie : Eine aktuelle Standortbestimmung. J Orofac Orthop 2011;72(3):165-86. https://doi.org/10.1007/s00056-011-0023-6

9. Davis SM, Plonka AB, Fulks BA, Taylor KL, Bashutski J. Consequences of orthodontic treatment on periodontal health: Clinical and microbial effects. Semin Orthod 2014;20(3):139-49. https://doi.org/10.1053/j.sodo.2014.06.002

10. Calniceanu H, Stratul S-I, Rusu D, Jianu A, Boariu M, Nica L, et al. Changes in clinical and microbiological parameters of the periodontium during initial stages of orthodontic movement in patients with treated severe periodontitis: A longitudinal site level analysis. Exp Ther Med 2020;20(6):1-1.

https://doi.org/10.3892/etm.2020.9329

11. Almeida RC, Capelli J, Teles RP. Levels of gingival crevicular fluid matrix metalloproteinases in periodontally compromised teeth under orthodontic forces. Angle Orthod 2015;85(6):1009-14. https://doi.org/10.2319/101714-744.1

12. Rotundo R, Bassarelli T, Pace E, Iachetti G, Mervelt J, Pini Prato G. Orthodontic treatment of periodontal defects. Part II: A systematic review on human and animal studies. Prog Orthod 2011;12(1):45-52. https://doi.org/10.1016/j.pio.2011.02.008

13. Garg N, Roychodhury S, Kumar V, Pal Singh V. Orthodontic treament and the compromised periodontal patient. J Adv Med Dent Scie Res 2015;3(2):148-152.

14. Zasčiurinskiene E, Lund H, Lindsten R, Jansson H, Bjerklin K. Outcome of periodontal-orthodontic treatment in subjects with periodontal disease. Part II: A CBCT study of alveolar bone level changes. Eur J Orthod 2019;41(6):565-74.

https://doi.org/10.1093/ejo/cjz039

15. Pini Prato GP, Chambrone L. Orthodontic treatment in periodontal patients: The use of periodontal gold standards to overcome the "grey zone." J Periodontol 2020;91(4):437-41. https://doi.org/10.1002/JPER.19-0306

16. Zasciurinskiene E, Lindsten R, Slotte C, Bjerklin K. Orthodontic treatment in periodontitis-susceptible subjects: a systematic literature review. Clin Exp Dent Res 2016;2(2):162-73. 
https://doi.org/10.1002/cre2.28

17. Re S, Cardaropoli D, Abundo R, Corrente G. Reduction of gingival recession following orthodontic intrusion in periodontally compromised patients. Orthod Craniofacial Res 2004;7(1):35-9.

https://doi.org/10.1111/j.1601-6343.2004.00277.x

18. Rotundo R, Nieri M, Iachetti G, Mervelt J, Cairo F, Baccetti T, et al. Orthodontic treatment of periodontal defects. A systematic review. Prog Orthod 2010;11(1):41-4.

https://doi.org/10.1016/j.pio.2010.04.013

19. Harshita N. Perio-Ortho Interactions-A Review. J Pharm Sci Res 2018;10(5):1053-6.

20. Gorbunkova A, Pagni G, Brizhak A, Farronato G, Rasperini G. Impact of orthodontic treatment on periodontal tissues: A narrative review of multidisciplinary literature. Int J Dent 2016;2016. https://doi.org/10.1155/2016/4723589

21. Martin C, Celis B, Ambrosio M, Bollain J, Antonoglou GN, Figuero E. Effect of orthodontic therapy in periodontitis and non-periodontitis patients: a systematic review with meta-analysis. J Clin periodontol 2021.

https://doi.org/10.1111/jepe.13487

22. Zhang J, Zhang AM, Zhang ZM, Jia JL, Sui XX, Yu LR et al. Efficacy of combined orthodontic-periodontic treatment for patients with periodontitis and its' effect on inflammatory cytokines: A comparative study. Am J Orthod Dentofacial Orthop 2017;152:494-500.

https://doi.org/10.1016/j.ajodo.2017.01.028

23. Panwar M, Jayan B, Arora V, Singh S. Orthodontic management of dentition in patients with periodontally compromised dentition. J Indian Soc Periodontol 2014;18(2):200-4. https://doi.org/10.4103/0972-124X.131325

24. Gkantidis N, Christou P, Topouzelis N. The orthodontic-periodontic interrelationship in integrated treatment challenges: A systematic review. J Oral Rehabil 2010;37(5):377-90. https://doi.org/10.1111/j.1365-2842.2010.02068.x

\section{ORTHODONTIC TREATMENT OF COMPROMISED PERIODONTAL TISSUES}

\section{J. Žekonienė, L. Linkevičienė, M. Ralytė}

Keywords: periodontic-orthodontic treatment, compromised periodontal tissues, orthodontic treatment and periodontal diseases.

Summary

Periodontal diseases are one of the most common diseases in the world and their increased incidence is observed in the adult population. Nowadays, as there is an increased demand for aesthetics, efficient chewing function, and the overall better quality of life, adults, often already suffering from periodontal pathology, are willing to begin orthodontic treatment. When the condition of patient's periodontal tissues is stable, the latter treatment is not contraindicated, but before making practical decisions in dealing with such clinical situations, it is necessary to know what are the effects of orthodontic treatment on periodontal tissues.

Objective: after the analysis of scientific literature, to provide scientific substantiation for the following aspects of the influence of orthodontic treatment on compromised periodontal tissues: 1) inflammatory and microbiological changes of compromised periodontal tissues during orthodontic treatment, 2) influence of orthodontic movements on compromised periodontal tissue, 3 ) effect of combined periodontal - orthodontic treatment on compromised periodontal tissues, 4) negative effects of orthodontic treatment on compromised periodontal tissues.

Material and methods: scientific articles published in 20002021 years period were searched in Medline (via PubMed), Google Scholar, and ScienceDirect scientific databases. The literature was selected on the basis of the following criteria: 1) articles describing orthodontic treatment of a periodontal patient, 2) articles demonstrating the positive/negative effect of orthodontic treatment on the recovery of periodontal defects, 3) articles indicating aspects to be considered by periodontists and orthodontists during interdisciplinary treatment plan.

Conclusions: when the condition of periodontal tissues is stable, orthodontic treatment is not contraindicated and has mostly positive effects on the repair of compromised periodontal tissues. Inflammatory and microbiological changes are being observed when orthodontic treatment starts, but do not progress in a negative way and do not cause any active periodontal disease. Orthodontic movements do not cause resorption of alveolar bone and somewhere its' apposition is being observed. With the methods of orthodontics, correction of bony and soft tissue defects caused by periodontal pathology is possible and further destruction of the tooth support apparatus is prevented. Clinical indicators of periodontal health after combined periodontal - orthodontic treatment are better compared to those achieved after periodontal treatment alone. The negative effects of orthodontic treatment on the periodontal tissues include a deterioration of the crown - root ratio, teeth mobility or even their loss.

Correspondence to: modesta.ralyte@mf.stud.vu.lt

Gauta 2021-10-19 